\title{
The Impact of Proximity on Consumer Fair Trade Engagement and Purchasing Behavior: The Moderating Role of Empathic Concern and Hypocrisy
}

\author{
Alvina Gillani ${ }^{1} \cdot$ Smirti Kutaula ${ }^{2} \cdot$ Leonidas C. Leonidou $^{3} \cdot$ Paul Christodoulides $^{4}$
}

Received: 19 April 2018 / Accepted: 27 August 2019 / Published online: 9 September 2019

(c) The Author(s) 2019

\begin{abstract}
The article reports the findings of an empirical study among consumers, regarding the impact of physical, social, and psychological proximity on their engagement to the fair trade idea and purchasing behavior. Based on a random sample of 211 British and 112 Indian consumers and using structural equation modeling, it was found that high levels of physical, social, and psychological proximity leads to high consumer fair trade engagement. Moreover, consumer fair trade engagement was confirmed to have a positive impact on fair trade purchasing behavior. Furthermore, consumer empathic concern was found to positively moderate the association between proximity and consumer fair trade engagement, while the opposite was true with regard to consumer hypocrisy. Finally, consumer nationality was found to have a control effect on physical, social, and psychological proximity, with the latter felt stronger among Indian, as opposed to British consumers.
\end{abstract}

Keywords Consumer engagement $\cdot$ Fair trade $\cdot$ Consumer proximity $\cdot$ Empathic concern $\cdot$ Hypocrisy

\section{Introduction}

Consumers worldwide are increasingly becoming aware of the social, economic, and environmental consequences of their consumption and are modifying their preferences, attitudes, and behaviors accordingly. One significant movement that has influenced such consumption patterns globally is that of fair trade (FT), defined as "a trading partnership,

Alvina Gillani

a.gillani@surrey.ac.uk

Smirti Kutaula

s.kutaula@kingston.ac.uk

Leonidas C. Leonidou

leonidas@ucy.ac.cy

Paul Christodoulides

paul.christodoulides@cut.ac.cy

1 Surrey Business School, University of Surrey, Surrey GU2 7XH, UK

2 Kingston Business School, Kingston University, Kingston upon Thames KT2 7LB, UK

3 University of Cyprus, P.O. Box 20537, 1678 Nicosia, Cyprus

4 Cyprus University of Technology, P.O. Box 50329, 3603 Limassol, Cyprus based on dialogue, transparency and respect that seeks greater equity in international trade. It contributes to sustainable development by offering better trading conditions to, and securing the rights of, marginalized producers and workers-especially in the South" (Moore 2004). In fact, the FT business model seeks to re-establish a more equitable environment in international trade, which will enable a more equitable distribution of wealth among marginalized producers/workers (Nicholls and Huybrechts 2016; Davies and Doherty 2018).

Consumer support to marginalized producers/workers is manifested through a variety of ways, such as actively petitioning government/local authorities to support FT, canvassing for changes in conventional trading, donating to pertinent causes, and raising awareness about the living standards of producers/workers from developing countries (Loureiro and Lotade 2005; Chatzidakis et al. 2016). The epitome of this support is for consumers to proceed with the purchase of FT products, because this denotes a positive predisposition toward maintaining fair prices in the market, caring about the living conditions of marginalized producers/workers, and helping secure a regular and fair income for poor people (Doherty et al. 2013).

This unique ethical consumer behavior caused by FT products has caught the attention of a number of researchers 
in recent decades, producing numerous articles on the subject (Andorfer and Liebe 2012; Chatzidakis et al. 2016). Despite the useful insights offered by this line of research, it suffers from a number of gaps: (a) there has been little, if any, emphasis on the role of consumer proximity to marginalized producers/workers from developing countries (Anderson 2018); (b) the critical role of consumer engagement as a driving force in purchasing FT products has been only tangentially tackled in extant research (Adams and Raisborough 2010); (c) the contingent role of various factors pertaining to personal traits of individuals on FT engagement has rarely been examined, although there are hints that these may be responsible for differences in consumer FT behavior (Hwang and Kim 2018); and (d) despite significant differences in their attitudes, habits and preferences, most FT consumption studies focused on consumers from developed rather than emerging countries, thus providing an incomplete picture on the subject (Sheth 2011; Narasimhan et al. 2015).

In light of the above gaps, our aim is to better understand the dynamics of FT consumer behavior in both developed and emerging market contexts (Andorfer and Liebe 2012; Anderson 2018). Specifically, the objectives of our study are fourfold: (a) to determine the extent to which the three proximity dimensions (i.e., physical, social, psychological) impact on consumer FT engagement; (b) to examine the influence of consumer FT engagement on his/her FT purchasing behavior; (c) to investigate the moderating role of empathic concern and hypocrisy on the relationship between the various proximity dimensions and consumer FT engagement; and (d) to examine the role of consumer nationality, whether residing in a developed or an emerging country, on each of the three proximity dimensions.

Our study contributes to the pertinent literature in various ways: first, it is among the first studies to raise the issue of consumer proximity in relation to the engagement of consumers with FT issues; second, it focuses on the role of consumer FT engagement in influencing purchasing decisions with regard to FT products; third, it introduces two important, but relatively unexplored, psychological constructs, namely empathic concern and hypocrisy, that could play a moderating role on the relationship between proximity dimensions and consumer FT engagement; and finally, it draws useful comparisons on proximity perceptions by consumers in developed (i.e., the United Kingdom) versus emerging (i.e., India) market contexts, due to economic, socio-cultural, or political-legal differences.

The rest of the article is structured as follows: first, we present a review of the extant literature on FT consumer behavior and summarize the main findings. Subsequently, we explain the key aspects of Social Identity Theory and how this can be related to the FT idea. Then, we propose a conceptual model and develop a set of research hypotheses. This is followed by an explanation of the methodology used in collecting and analyzing the data of the study. The next section presents the findings with regard to the various hypotheses set. Then, conclusions, as well as theoretical and managerial implications are derived from the study. The final section refers to the limitations of the study and directions for future research.

\section{Prior Research on FT Consumer Behavior}

Research on FT consumer behavior first made its appearance in the early 1990s, with studies on the subject taking five different directions (see Table 4 in Appendix for a summary of recent empirical studies). The first group of studies examines consumers' willingness to pay (WTP) for FT products. These were mainly anchored on Random Utility Theory (McFadden 1974), which postulates that enhancing the utility of an object guides consumer decision-making in a way to choose the option with the maximum utility. However, empirical results are mixed: while some studies (e.g., De Pelsmacker et al. 2005; Loureiro and Lotade 2005; Trudel and Cotte 2009) show that consumers express their willingness to pay an ethical premium for FT labeled products, others (e.g., Basu and Hicks 2008; Cailleba and Casteran 2010) indicate that consumers consider the ethical premium to have a negative impact on their purchase decision. This is because, as opposed to the former group of consumers, the latter possess ethical values that are undermined by utilitarian considerations (McFadden 1974; Mahé 2010).

The second line of research examines FT-purchasing behavior, using Schwartz's and Rokeach's value frameworks. Based on Schwartz's value system, it was found that universalism, benevolence, self-direction, and stimulation are crucial in guiding individual FT consumption (Doran 2009, 2010; Ma and Lee 2012). On the other hand, Ladhari and Tchetgna (Ladhari and Tchetgna 2015) revealed that the dominant values underlying Canadian FT consumers are social justice and equality. In addition, De Ferran and Grunert (2007) found that French consumers buying FT products from specialized stores are motivated by values related to protecting the environment, whereas supermarket purchases for these products were mainly associated with concerns for human rights and social responsibility.

The third stream of studies adopts a social psychological lens, mainly using the Theory of Planned Behavior (TPB) to examine consumers' attitudes, motivations, and intentions to buy FT products. For example, Shaw et al. (2000) and Ozcaglar-Toulouse et al. (2006) found that the predictive power of TPB increases when ethical obligation and ethical self-identity are added to the TPB. In challenging the TPB logic, some scholars (e.g. Yamoah et al. 2016) modify TPB to better predict FT consumption behavior and bridge what is called the attitude-behavior gap. For example, by 
surveying Dutch consumers, Graafland (2017) suggested that adherence to the tenets of Christian religiosity boosts positive sentiments toward FT, thus increasing investment in FT products. Adopting a social perspective, Reese and Kohlmann's (2015) survey among German consumers showed that consumers purchasing FT products identify themselves as global citizens caring for humanity as a whole, and that this global identification guides their consumption patterns. In a similar vein, Varul (2009) contended that the self-identification of a consumer as a purchaser of FT goods acts as a distinction from conventional shopping and serves in the self-construction of a moral persona.

The fourth group of studies presents findings from a marketing standpoint. Some researchers examined the role of product labels incorporating social and environmental messages on FT product purchase by consumers (Basu and Hicks 2008; Howard and Allen 2010). However, while some studies found that consumer purchase intentions are stronger regarding products labeled 'Fair Trade' (De Pelsmacker et al. 2005), others reported a minimal influential role by such social labels (Poelman et al. 2008). Further, by analyzing the effect of ethical product information on consumers' purchase decisions, Osburg et al. (2017) proposed that the greater the consumer awareness and knowledge of ethical (and organic) production, the less was the impact of price on consumer decision-making.

The final set of studies adopts a cross-cultural perspective, suggesting that culture impinges on FT consumer behavior (Andorfer and Liebe 2012). Although, FT by default, transcends national boundaries, this is manifested differently across countries (Varul 2009). For instance, employing Schwartz's value system, US FT consumers reported a high score in universalism (Doran 2009), while British FT consumers were led mainly by the values of equality, hedonism, and self-direction (Shaw et al. 2005). In addition, research by Kim et al. (2010) demonstrated that, while product loyalty to FT in the US was predicated on ethical consumption values, in South Korea, this was based on corporate evaluation issues.

\section{Theoretical Background}

Our study is theoretically anchored on Social Identity Theory (SIT) and extends current research on proximity and consumer behavior by examining the impact of proximity on consumer FT engagement and subsequent buying behavior. Underpinned by a socio-psychological viewpoint, SIT posits that groups of people will coalesce around a cause or subject with which they can identify and draw a group identity, leaving those who are not part of that group, outside the group (Tajfel and Turner 1979).
Social identity is an important aspect of self-worth, confidence, and pride, which a person strives to attain from members of the groups they identify with (Tajfel and Turner 1979). SIT has been adopted widely in the management literature, specifically in the area of organizational psychology, where it has been argued that an individual's identification with the organization is more likely to produce positive attitudes and behaviors toward this organization (Ashforth and Mael 1989; Zhu et al. 2017).

The sense of proximity - physical, social, psychological-which a consumer experiences, dictates the degree to which s/he will identify with marginalized producers/workers. For example, when, as a result of socially responsible initiatives by a company, a consumer is persuaded to identify with this company, s/he will act in ways which are socially meaningful, rather than individually instrumental. This is because socially responsible practices affect both the consumers' self-identification with that enterprise, their evaluation of it, and their purchase intention (Sen and Bhattacharya 2001; Mohr and Webb 2005).

Socially responsible practices have the potential to affect consumers' purchasing intentions, both directly-wherein the activity of the enterprise matches the consumers' beliefs and support for the ideas-and indirectly, through the purchase of products (Sen and Bhattacharya 2001). Based upon this rationale, when consumers perceive proximity (physical, social or psychological) with marginalized producers/ workers, this will strengthen the bond between consumers and marginalized producers/workers, bringing them into 'membership' of the same family. It will also advance the cause of the FT movement and provide financial support for marginalized producers/workers through the purchase of FT products.

\section{Conceptual Model and Hypotheses}

Figure 1 presents our conceptual model, which consists of seven constructs connected with six hypothesized links. Specifically, we propose that proximity (whether physical, social or psychological) with FT producers/workers is a crucial precondition for consumer engagement with FT. In turn, FT engagement on the part of the consumer will promote investment by purchasing FT products. We also contend that the consumer's level of empathic concern and hypocrisy will moderate the relationship between FT engagement and FT purchasing behavior. Finally, we set consumer nationality as a control variable on the three dimensions of proximity.

\section{Main Hypothesized Paths}

Proximity is defined as the "feeling that the moral agent has for victims (beneficiaries) of the evil (beneficial) act 
Fig. 1 The conceptual model

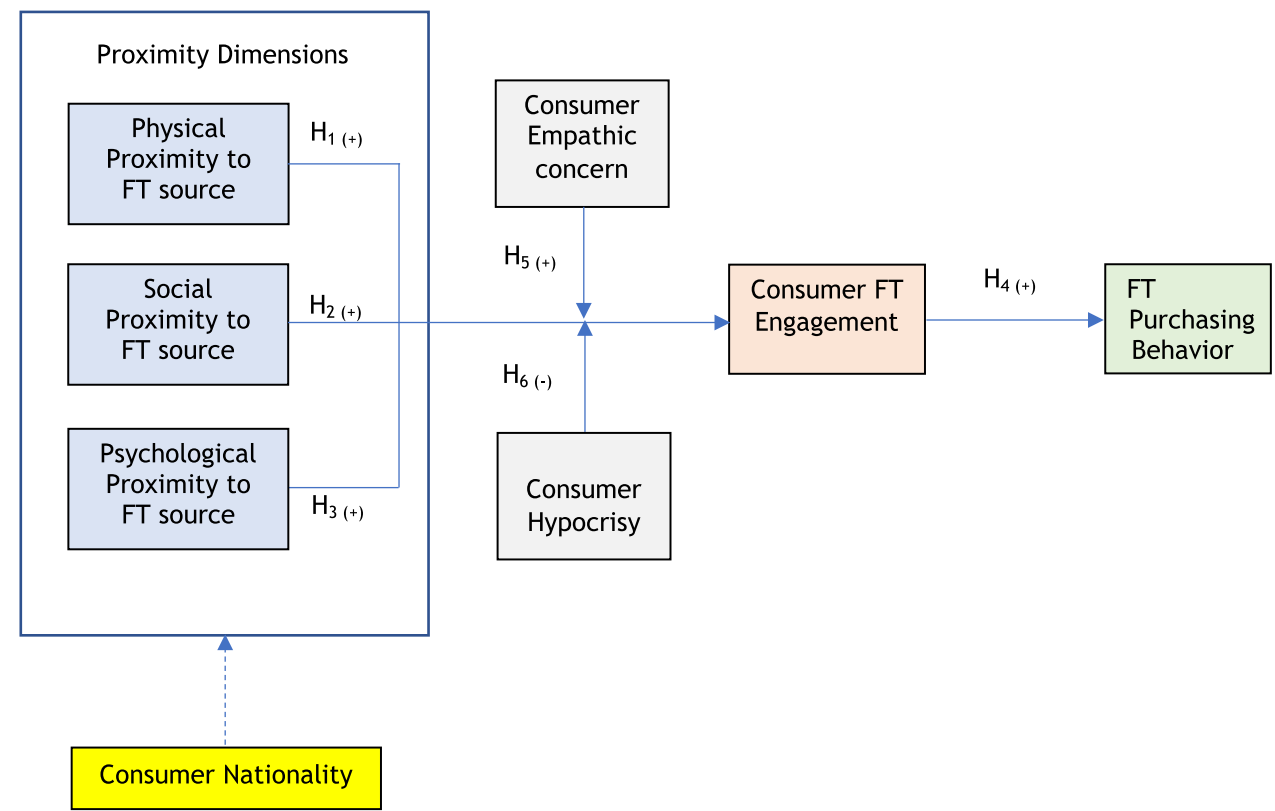

in question" (Jones 1991, p. 376) and comprises physical, social, and psychological dimensions. Contextualizing proximity in FT purchase decision-making implies that consumers (moral agents) who are physically, socially, and psychologically closer to marginalized producers/workers could be affected more by the issues around their living conditions.

Physical proximity refers to the geographical nearness between someone making a decision or performing an action and those affected by this decision or act (Jones 1991). When examined in an ethical or moral context, it was found that physical proximity enhances helping behavior (Grau and Folse 2007; Adams and Raisborough 2008; Chang 2012). For instance, Grau and Folse (2007), in examining the impact of nearness of donation activity and the nature of messages on consumers' attitudes and intentions, revealed that a donation is more likely when local people are involved and hence, identify with the cause. Although FT is a movement initially developed to connect consumers in the global north to the marginalized producers/workers of the global south, recent developments in consumer markets indicate that FT is no longer limited to the north but it also extents to emerging economies with serious implications for physical proximity between consumers and marginalized producers/workers (Alexander and Nicholls 2006; Doherty et al. 2013). Although the role of physical proximity has not yet been examined within a FT context, Adams and Raisborough's (2010) study among British consumers indirectly found that 'closer to home' describes a consumer type whose consumption preferences are predicated upon products being local. They also revealed that most participants expressed a common concern, namely promoting and looking out for the welfare of others. However, there was a vast difference in whom and why they perceived some parties as a deserving beneficiary, which then had an impact on whether they backed FT products from marginalized producers/workers or supported local British goods. The above suggest that:

$\mathrm{H}_{1}$ The closer the physical proximity of consumers to marginalized producers/workers, the more the consumer FT engagement.

Social proximity exists when people share a social familiarity based on collective experiences, deriving from closeness in terms of values, norms, customs, family, background, and beliefs (Boschma 2005). Ghorbani et al. (2013) suggest that social proximity is an empowering factor in ethical behavior, grouping the social ties into strong and weak. It is proposed that social identification increases as a function of commitment or a feeling of familiarity to a group and this influences behavioral outcomes (Mencl and May 2009). It is the founding intention of FT that the norms and values of society be changed to reveal people, places, and relations responsible for the commodities, which can facilitate the change where consumers could be more actively engaged with FT instead of passive involvement (Golding and Peattie 2005). As Raynolds (2000) puts it, greater understanding of the socio-cultural traits of marginalized producers/workers by consumers helps in understanding the invisible forces that govern the marketplace. In other words, consumers' social proximity, that is, familiarity with the values, norms, customs, and beliefs of marginalized producers/workers, is more likely 
to influence their engagement with FT issues (Narasimhan et al. 2015). Hence, the following hypothesis can be made:

$\mathrm{H}_{2}$ The closer the social proximity of consumers to marginalized producers/workers, the more the consumer FT engagement.

Psychological proximity is described as an affective propinquity or a 'high level of commitment' (Mencl and May 2009, p. 206). This commitment is directed towards those who are close to the decision-maker, such as family members and close friends (Ghorbani et al. 2013). In a FT context, it is the subjective experience of perceived closeness to marginalized producers/workers from developing countries. Psychological proximity can be generated, for example, through media coverage, awareness programs, and personal visits to these countries. FT organizations, striving to increase awareness of their raison d'être, generate national marketing awareness campaigns, demonstrating the quintessential differences between the FT process and the traditional model, thus enhancing the psychological proximity between consumers and impoverished producers/workers (Nicholls and Lee 2006). Thus, to some extent, the distancing, out-group aspects of the far-away producer/ worker (Turner and Tajfel 1986) can be ameliorated as the consumer begins to develop a genuine rapport, overcoming the out-group aspects of 'disadvantaged producers in farflung corners of the globe' (Doran 2010, p. 538), which s/ he demonstrates by engaging in FT concerns (Doran 2009). Further, De Ferran and Grunert (2007) found that consumers supporting FT products were motivated by a desire for greater equality among mankind, resulting in an enhanced psychological proximity with the marginalized producers/ workers. In other words, increased psychological proximity between consumers and marginalized producers/workers results in heightened involvement and investment in the FT ethos. Therefore, we may posit the following:

$\mathrm{H}_{3}$ The closer the psychological proximity of consumers to marginalized producers/workers, the more the consumer FT engagement.

Customer engagement is defined as a process by which a customer becomes actively involved with the brand, including and beyond purchase (Hollebeek et al. 2014; Vivek et al. 2014; Pansari and Kumar 2017; Gupta et al. 2018). It is a multifaceted concept, which includes such dimensions as cognitive, behavioral, social, and emotional aspects (Vivek et al. 2012), as well as brand interaction and identification (So et al. 2014). Customer engagement creates value for businesses (Pansari and Kumar 2017) and as such it can be demonstrated as having links with customer satisfaction and loyalty (Bowden 2009; Van Doorn et al. 2010; Vivek et al. 2012). From an ethical consumption perspective, customer engagement influences FT purchase behavior. This is because ethical engagement permits consumers to demonstrate a feeling of responsibility toward society and their admiration of businesses employing socially responsible approaches, as expressed by purchasing products which have positive, moral, and ethical qualities. This contrasts to exploitative and unethical firms (such as those classified as 'modern slavery'), which are scrupulously avoided (de Pelsmacker et al. 2005; Andorfer and Liebe 2015). In fact, there is empirical evidence showing that consumers, for whom ethical issues are of concern, are likely to change their behavior and buy FT products to support marginalized producers/workers (e.g., Nicholls and Lee 2006; OzcaglarToulouse et al. 2006; Bray et al. 2011; Hassan et al. 2016). Although the addition of an ethical premium to the price of FT merchandise as a means of providing a remittance to marginalized producers/workers may be considered negatively by some consumers, others may regard it as a validation of the product which represent the fight against poverty, exploitation, and slavery (Thompson and Coskuner-Balli, 2007). Hence, we can argue that:

$\mathrm{H}_{4}$ The more the consumer FT engagement, the higher the propensity by the consumer to purchase FT products.

\section{Moderation Hypotheses}

Empathy is defined as a moral emotion deriving from sentiments of wishing to benefit a person in need, thus demonstrating concern for the wellbeing of others (Batson et al. 1988). Empathy comprises two distinct dimensions, perspective taking and empathic concern. While perspective taking (or cognitive empathy) suggests that the empathiser is not only aware of, but also adopts the perspectives of the other person, in the case of empathic concern (or affective empathy) the empathiser has moral feelings and emotions of warmth and compassion toward others (Davis 1980, 1983; Kamdar et al. 2006; Chowdhury and Fernando 2014). In this study, we focus on empathic concern, because it allows the consumers to express the emotions of sympathy and compassion toward the plight of marginalized producers/ workers, rather than perspective taking, which involves stepping in others' shoes which, for proximity reasons (e.g., physical, social, etc.), may be unachievable for many consumers. Support for the argument that moral emotions of empathic concern, including compassion and care for others, enhance engagement with ethical decision-making is found in a number of studies (Batson et al. 1988; Basil et al. 2008; Mencl and May 2009; Kim and Kou 2014). For example, Mencl and May (2009), in a study involving HR professionals, found that empathic concern moderates the relationship 
between physical proximity and ethical decision-making process. In addition, in examining children's attitudes toward FT, Nicholas and Lee (2006) found that empathic concern led to involvement with FT issues as they could psychologically relate to the issues of child labor.

Notably, high empathic concern will strengthen the positive impact of proximity on customer FT engagement, because it allows individuals to feel the plight of others and generate an affective state of unhappiness and sadness (Hwang and Kim 2018). To alleviate these negative feelings, consumers will seek to collaborate with and actively participate in FT networks (as activists, buyers, etc.), expressing in this way their affiliation and sympathy toward these marginalized producers/workers (Ballet and Carimentrand 2010; Peattie and Samuel 2018). On the other hand, lower levels of empathic concern dampen the impact of physical, social, and psychological proximity on consumer engagement with FT issues due to an indifference to the working conditions and living of marginalized producers/workers. In fact, people with low-empathic concern tend to care more about their self-interests rather than the interests of the society, weakening in this way the favorable impact of proximity on consumers engaging with the FT ethos (Doran 2010; Peattie and Samuel 2018). Hence, we can hypothesize that:

$\mathrm{H}_{5}$ Consumer empathic concern positively moderates the association between (a) physical proximity, (b) social proximity, and (c) psychological proximity with consumer FT engagement.

Hypocrisy is defined as a "motivation to appear moral yet, if possible, avoid the cost of actually being moral.... it allows one to engender trust, and still relentlessly pursue personal gain" (Batson et al. 2006, p. 321). It takes place when a person's deeds do not align with their words (Wagner et al. 2009). In this vein, research pertaining to ethical consumption suggests that often consumers' words and actions are misaligned, also known as the 'attitude-behavior gap', and that the desire to appear ethical is such that the consumer fabricates an untrue attitude-a false persona (Boulstridge and Carrigan 2000; Carrington et al. 2010, 2014; Hassan et al. 2016; Park and Lin 2018: Gamma et al. 2018). For example, in the context of FT, while on one hand some consumers are willing to pay more for local products (and therefore, price appeared less of an issue), they are not willing to pay extra for FT products since the consumer finds it easier to relate to buying local products (Adams and Raisborough 2010). Hypocritical consumers may also use the uncertainties associated with geographic and psychic distance from marginalized producers/workers as a pretext for failing to engage with FT.

This moderating role of hypocrisy can be justified by the fact that consumers who show inconsistent behaviors when compared to their attitudes toward FT are less likely to engage with the FT ethos, even though they perceive themselves to be close to marginalized producers/workers. Indeed, consumers who demonstrate higher levels of physical, social, and psychological proximity, when coupled with hypocrisy, tend not to tie in their behaviors the moral principles and social norms they advocate. As a result, this perceived proximity with the marginalized producers/workers may not necessarily translate into active involvement with the FT ethos, even if the consumers harbor positive attitudes toward FT (Carrington et al. 2014; Shaw et al. 2016). In contrast, in the case of consumers characterized by lower levels of hypocrisy, their proximity to marginalized producers/workers will show stronger effects on engagement with the FT ethos. This is because when consumers are less hypocritical, their moral beliefs are well aligned with their behaviors, thus displaying more commitment toward marginalized producers/workers (Hassan et al. 2016; Park and Lin 2018). Based on the above, we can hypothesize that:

$\mathrm{H}_{6}$ Consumer hypocrisy negatively moderates the association between (a) physical proximity, (b) social proximity and (c) psychological proximity with consumer FT engagement.

\section{Study Method}

\section{Sampling Procedures}

Data were collected through a Qualtrics panel, a research agency having branches in multiple countries, using various sources to offer respondents for completing online surveys. This method of recruiting panelists for data collection has been used widely in business research recently and thus was deemed appropriate for the cross-country focus of our study (Ward and Dahl 2014; Kumar and Pansari 2016; Merz et al. 2018). Respondents were qualified to take part in the study if they were aware of the concept of FT and FT products. To avoid leading the consumers, we gave them options of ethical issues, such as animal rights, recycling, climate change, and FT, and only when the FT option was selected could consumers proceed to participate in the study.

While we acknowledge the limitations related to the use of such data collection methods, such as identity checks, response integrity, sampling issues, and data quality issues (Lowry et al. 2016), these were addressed by following Smith et al.'s (2016) recommendations: first, we utilized attention check items to filter panelists that did not devote adequate time to answer all questions; second, we included reverse coded items for various constructs to avoid random responses; third, we eliminated responses that were completed very quickly as compared to the average response time, thus avoiding speeding issues; fourth, we checked 
for response duplications by reviewing respondents' IP addresses; finally, we included several screening questions to ensure response quality.

\section{Construct Operationalization}

With regard to the operationalization of constructs, we used only published, validated measures, with the exception for proximity where there was no readily available scale (see Table 5 in Appendix). Consumer FT engagement comprised 19 items adopted from So et al. (2014), measuring the four dimensions of engagement, namely, enthusiasm (4 items), attention (5 items), absorption (5 items), and interaction (5 items). FT purchasing behavior includes five items taken from Hollebeek et al. (2014); Sudbury-Riley and Kohlbacher (2016) and Zanjani et al. (2016) and adapted it to our context. Empathic concern was measured using a 7-item scale adopted by Kamdar et al. (2006), which in fact is a short version of the interpersonal reactivity index (IRI) developed by Davis (1980), which comprises 28 items. For the hypocrisy construct, we reviewed the measure of corporate hypocrisy developed by Wagner et al. (2009) and adjusted it from the perspective of consumers.

For the construct of proximity, in the absence of established scales due to limited empirical research on the relationship between proximity and ethical consumer decisionmaking, we had to develop a new scale that captures its three dimensions, namely physical, social, and psychological. In doing so, we followed the scale development and validation procedure suggested by Churchill (1979). First, we based the item generation phase on thoroughly reviewing the existing literature and carrying in-depth interviews with eight British and six Indian consumers. This has contributed to generating an exhaustive list of items that could be of relevance to each of the three dimensions of proximity. ${ }^{1}$ This list of items was subsequently presented to a panel of five academic experts, specializing in ethical business issues, to obtain their views about their suitability to operationalize proximity. Some items had to be deleted, others had to be adjusted, while some other new items had to be added. The resulting list of items was allocated by the panel experts to each of the three dimensions of proximity. These were in turn thoroughly reviewed with the assistance of 15 British

\footnotetext{
${ }^{1}$ Notably, the review of the literature revealed little empirical research on the relationship between proximity and ethical consumer decision-making (Mencl and May 2009). In fact, the few studies focusing on proximity used manipulation scenarios, employed simple measures, and covered only few aspects of proximity. For example, Ghorbani et al.'s (2013) study measured only psychological proximity and simply used only one item in a manipulation check as follows: "Participants indicated how close they felt to each owner on a 5-point scale $(1=$ not close at all, $5=$ very close $) . "$.
}

and 12 Indian consumers to confirm their nomological validity. This process resulted in obtaining four items for physical proximity, five items for social proximity, and five items for psychological proximity.

\section{Questionnaire Design}

The questionnaire included a list of pre-coded questions which were reflecting the scales derived from the prior literature or were self-developed. These were measured on a 5-point Likert type scale, ranging from 1 (strongly disagree) to 5 (strongly agree). We also included a section in the questionnaire requiring information about the demographic characteristics of respondents, namely age, gender, education level, and residential area. Prior to starting the complete study, we pilot-tested the questionnaire with five British and five Indian consumers (using face-to-face interviews) to confirm its workability in terms of flow, structure, and length, revealing no problems.

\section{Data Collection}

Our fieldwork took place in two countries, namely the United Kingdom (a developed country) and India (an emerging economy), which overall are characterized by different levels of proximity from marginalized producers/workers based in developing countries. Altogether, we received 323 responses, 211 from the United Kingdom and 112 from India. $^{2}$ The demographic profile of the UK sample versus that of the Indian sample exhibited differences, attributable mainly to differences in the overall population structure of the two countries. Specifically, British respondents had the following demographic profile: gender (male: $46.2 \%$, female: $53.8 \%$ ), age group (18-24 years: $21.5 \%, 25-34$ years: $25.7 \%$, 35-44 years: $15.0 \%, 45-54$ years: $20.0 \%, 55-64$ years: $17.8 \%$ ), and level of education (primary: $0.5 \%$, secondary: $56.0 \%$, undergraduate: $29.6 \%$, postgraduate: $13.9 \%$ ). On the other hand, the demographic profile of the Indian respondents was the following: gender (male: $58.5 \%$, female: $41.5 \%$ ), age group (18-24 years: $14.5 \%, 25-34$ years: $59.1 \%$, 35-44 years: $18.2 \%, 45-54$ years: $4.6 \%, 55-64$ years: $3.6 \%$ ),

\footnotetext{
2 The difference in the size of the British versus the Indian sample is because the Qualtrics research agency faced more difficulties in finding respondents in India, as opposed to the UK, who could qualify to participate in the study. This can be attributed to the fact that the FT concept is relatively less developed among Indian than British consumers. In the UK, 223 out of 1222 respondents (i.e., 18.2\%) were aware of FT issues. After discarding incomplete questionnaires, 211 consumers comprised the final UK sample. In India, 123 out of 946 respondents (i.e., 13.0\%) were aware of FT issues. Following exclusion of questionnaires with incomplete data, 112 consumers remained in the final Indian sample.
} 
and level of education (primary: $13.8 \%$, secondary: $65.1 \%$, undergraduate: $14.1 \%$, postgraduate: $7.0 \%$ ).

\section{Analytical Method}

We adopted structural equation modeling (SEM) to test the proposed conceptual model and the hypothesized relationships between the constructs, owing to three major reasons: (a) it allows simultaneous analysis of relationships hypothesized between the constructs of the model in a comprehensive manner; (b) it is based on confirmatory instead of an exploratory approach to the data analysis; and (c) it considers explicit estimates of measurement error, whereby the model fit is regarded (Hair et al. 2014). The analysis was performed using the EQS statistical program, which, compared to other available programs, places less stringent assumptions on the multivariate normality of the data (Bentler 2008).

\section{Research Findings}

In this section, we first present the results of the measurement model, followed by the results of the structural model. We then report the results of the moderation analysis, as well as those of control effects.

\section{Measurement Model}

With regard to the measurement model, using confirmatory factor analysis (CFA), each item was restricted to load on its a priori specified factor, while the underlying factors were allowed to correlate (Anderson and Gerbing 1988) (see Table 1). To estimate the model, we used the elliptical reweighted least-squares (ERLS) procedure, which is superior to other estimation techniques (Stump and Heide 1996). The Chi square statistic was found to be significant $\left(\chi^{2}=1173.62, p=0.000\right)$, which is not surprising given the sensitivity of this index of fit to sample size (Hair et al. 2014). However, the results of the alternative fit indices pointed to a good model fit, as all values were well within the commonly accepted critical levels (Byrne 2006). Specifically, the non-normed fit index (NNFI) was 0.95, the comparative fit index (CFI) was 0.97 , and the root mean square error of approximation (RMSEA) was 0.07.

Construct reliability was satisfactory because all constructs had Cronbach's alphas greater than the critical value of 0.70 . The same was also true with regard to composite reliability, because all coefficients being greater than 0.65 . In addition, we have examined convergent validity, which was verified because the $t$ value for each item was high and significant, all standard errors of the estimated coefficients were very low, and the average variance extracted for each construct was equal to or above 0.45 (Hair et al. 2014). With regard to discriminant validity, this was verified because the confidence interval around the correlation estimate for each pair of constructs examined never included 1.00, while the squared correlation for each pair of constructs never exceeded their average variance extracted (Fornell and Larcker 1981; Anderson and Gerbing 1988).

To check for common method bias, we first employed the Harman's single-factor test (Podsakoff and Organ 1986), where all questionnaire items were included in a principal component analysis with varimax rotation. Five separate factors with eigenvalues greater than 1.0 emerged from the unrotated factor solution, with these factors explaining $65.9 \%$ of the total variance (of which $19.8 \%$ was explained by the first factor). We also used a confirmatory factor approach, in which all items included in the measurement model were restricted to load on a single factor (Venkatraman and Prescott 1990). The model fit indices revealed very poor values, well below the commonly acceptable cut-off points (i.e., $\chi^{2}=3396.23, p=0.000$; $\mathrm{df}=527$; $\mathrm{NFI}=0.78$; $\mathrm{NNFI}=0.79 ; \mathrm{CFI}=0.80 ; \mathrm{RMSEA}=0.14)$. Finally, we used the partial correlation technique (Lindell and Whitney 2001), where a theoretically unrelated construct served as a marker variable. This neither exhibited a significant correlation with any other constructs used in the model nor changed the significance of the correlation coefficients after having the partial correlation adjustments. Based on the results of the above three tests, we can safely argue that there is no problem with common method bias.

\section{Structural Model}

We tested the hypothesized associations between the constructs by estimating the structural model using the elliptical re-weighted least squares (ERLS) technique. While the Chi square for the model was found to be significant $\left(\chi^{2}=1230.74, p=0.000\right)$, this was anticipated owing to the shortcomings of this statistic and thus is not solely relied upon when accepting or rejecting the model (Kline 2005). Therefore, we used the alternative fit indices, which showed an acceptable structural model fit $(\mathrm{NFI}=0.94 ; \mathrm{NNFI}=0.96$; $\mathrm{CFI}=0.96$; RMSEA $=0.08$ ). The standardized path coefficients, along with corresponding $t$ values of the structural model, are reported in Table 2. All the standardized path coefficients are statistically significant, thus providing support for the hypothesized paths.

The first three hypotheses examined the relationship between the three dimensions of proximity (i.e., physical, social, and psychological) with consumer FT engagement. With regard to $\mathrm{H}_{1}$, physical proximity was found to be conducive to the formation of consumer FT engagement ( $\beta=0.17, t=2.74, p=0.01)$. This suggests that physical proximity enhances the consumer engagement directed 
Table 1 Measurement model and summary statistics

\begin{tabular}{|c|c|c|c|c|c|c|c|c|c|c|}
\hline Constructs & Scale items & $\begin{array}{l}\text { Standard- } \\
\text { ized load- } \\
\text { ings }\end{array}$ & $t$ value & $\alpha$ & $\rho$ & AVE & Mean score & $\begin{array}{l}\text { Standard } \\
\text { deviation }\end{array}$ & Item mean & $\begin{array}{l}\text { Standard } \\
\text { deviation }\end{array}$ \\
\hline \multirow[t]{3}{*}{ Physical proximity } & PHP1 & 0.68 & $*$ & \multirow[t]{3}{*}{0.71} & \multirow[t]{3}{*}{0.66} & \multirow[t]{3}{*}{0.51} & \multirow[t]{3}{*}{4.00} & \multirow[t]{3}{*}{0.59} & 3.93 & 0.85 \\
\hline & PHP2 & 0.66 & 8.24 & & & & & & 4.09 & 0.69 \\
\hline & PHP3 & 0.71 & 8.75 & & & & & & 3.96 & 0.78 \\
\hline \multirow[t]{4}{*}{ Social proximity } & SCP1 & 0.78 & $*$ & \multirow[t]{4}{*}{0.82} & \multirow[t]{4}{*}{0.76} & \multirow[t]{4}{*}{0.54} & \multirow[t]{4}{*}{3.95} & \multirow[t]{4}{*}{0.61} & 4.01 & 0.77 \\
\hline & $\mathrm{SCP} 2$ & 0.78 & 12.95 & & & & & & 3.94 & 0.72 \\
\hline & $\mathrm{SCP} 4$ & 0.66 & 10.71 & & & & & & 3.84 & 0.78 \\
\hline & SCP5 & 0.71 & 11.67 & & & & & & 3.99 & 0.73 \\
\hline \multirow[t]{4}{*}{ Psychological proximity } & PSP1 & 0.63 & $*$ & \multirow[t]{4}{*}{0.82} & \multirow[t]{4}{*}{0.76} & \multirow[t]{4}{*}{0.54} & \multirow[t]{4}{*}{4.02} & \multirow[t]{4}{*}{0.58} & 4.19 & 0.65 \\
\hline & PSP2 & 0.77 & 10.20 & & & & & & 3.96 & 0.76 \\
\hline & PSP3 & 0.83 & 10.69 & & & & & & 3.92 & 0.74 \\
\hline & PSP5 & 0.69 & 9.34 & & & & & & 4.02 & 0.71 \\
\hline \multicolumn{11}{|l|}{ Consumer engagement $^{\mathrm{a}}$} \\
\hline \multirow[t]{4}{*}{ Consumer enthusiasm } & CEE1 & 0.68 & $*$ & \multirow[t]{4}{*}{0.86} & \multirow[t]{4}{*}{0.80} & \multirow[t]{4}{*}{0.61} & \multirow[t]{4}{*}{3.99} & \multirow[t]{4}{*}{0.65} & 3.89 & 0.75 \\
\hline & CEE2 & 0.85 & 12.01 & & & & & & 4.01 & 0.79 \\
\hline & CEE3 & 0.80 & 11.40 & & & & & & 4.07 & 0.74 \\
\hline & CEE4 & 0.80 & 11.45 & & & & & & 3.97 & 0.80 \\
\hline \multirow[t]{5}{*}{ Consumer attention } & CEA1 & 0.72 & $*$ & 0.90 & 0.85 & 0.65 & 4.09 & 0.64 & 4.24 & 0.72 \\
\hline & CEA2 & 0.84 & 13.13 & & & & & & 4.01 & 0.78 \\
\hline & CEA3 & 0.86 & 13.51 & & & & & & 4.07 & 0.73 \\
\hline & CEA4 & 0.81 & 12.60 & & & & & & 3.96 & 0.80 \\
\hline & CEA5 & 0.81 & 12.67 & & & & & & 4.15 & 0.76 \\
\hline Consumer absorption & CEB1 & 0.78 & $*$ & 0.89 & 0.84 & 0.64 & 4.00 & 0.69 & 3.99 & 0.87 \\
\hline & CEB2 & 0.90 & 15.67 & & & & & & 3.98 & 0.82 \\
\hline & CEB3 & 0.83 & 14.36 & & & & & & 4.02 & 0.81 \\
\hline & CEB4 & 0.83 & 14.28 & & & & & & 3.97 & 0.81 \\
\hline & CEB5 & 0.64 & 10.61 & & & & & & 4.05 & 0.83 \\
\hline Consumer interaction & CEI1 & 0.84 & $*$ & 0.90 & 0.84 & 0.65 & 4.04 & 0.65 & 4.10 & 0.78 \\
\hline & CEI2 & 0.81 & 15.54 & & & & & & 4.02 & 0.75 \\
\hline & CEI3 & 0.84 & 16.42 & & & & & & 4.01 & 0.78 \\
\hline & CEI4 & 0.86 & 17.04 & & & & & & 4.02 & 0.79 \\
\hline & CEI5 & 0.66 & 11.58 & & & & & & 4.05 & 0.76 \\
\hline FT purchasing behavior & FPB1 & 0.74 & $*$ & 0.85 & 0.79 & 0.60 & 4.00 & 0.65 & 3.94 & 0.82 \\
\hline & FPB2 & 0.82 & 12.85 & & & & & & 4.01 & 0.75 \\
\hline & FPB3 & 0.77 & 12.01 & & & & & & 4.04 & 0.76 \\
\hline & FPB5 & 0.77 & 12.04 & & & & & & 4.03 & 0.77 \\
\hline
\end{tabular}

${ }^{\mathrm{a}}$ Higher-order factor $(\mathrm{Mean}=4.03, \mathrm{StD}=0.56)$

*Fit statistics: $\chi^{2}=1173.62, p=0.000, \mathrm{df}=513 ; \mathrm{NFI}=0.95 ; \mathrm{NNFI}=0.97 ; \mathrm{CFI}=0.97 ; \mathrm{RMSEA}=0.072(0.067,0.077)$

toward FT issues, thus providing support for our first hypothesis. This is in line with Adam and Raisborough's (2010) study, where it was found that British consumers framed ethical consumption in terms of supporting physically proximate local British farmers because it benefits the local communities. Social proximity was also revealed to be positively linked with consumer FT engagement ( $\beta=0.56$, $t=6.76, p=0.00$ ), thus confirming $\mathrm{H}_{2}$. This is concurrent with previous FT research which contends that, consumers may benefit individuals within their social group (in group), and hence may distance themselves from engagement with FT as they consider marginalized producers/workers out group (Doran 2010). Thus, increased levels of social proximity can also lead to consumer FT engagement. $\mathrm{H}_{3}$ was also supported, since a positive relationship was established between psychological proximity and consumer FT engagement $(\beta=0.42, t=5.36, p=0.00)$. Our finding is consistent with the previous studies that the closer psychologically 
Table 2 Structural model results-main and control effects

\begin{tabular}{lllll}
\hline Hypothesis & Hypothesized path & $\begin{array}{l}\text { Standardized } \\
\text { path coeffi- } \\
\text { cients }\end{array}$ & $t$ value & $p$ value \\
& & & & \\
\hline Main effects & & 0.17 & 2.74 & 0.01 \\
$\mathrm{H}_{1}$ & Physical proximity $\rightarrow$ Consumer FT engagement & 0.56 & 6.76 & 0.00 \\
$\mathrm{H}_{2}$ & Social proximity $\rightarrow$ Consumer FT engagement & 5.36 & 0.00 \\
$\mathrm{H}_{3}$ & Psychological proximity $\rightarrow$ Consumer FT engagement & 0.42 & 7.74 & 0.00 \\
$\mathrm{H}_{4}$ & Consumer FT engagement $\rightarrow$ FT purchasing behavior & 0.84 & & \\
Control effects & & 0.86 & 7.08 & 0.00 \\
\multicolumn{7}{l}{ Consumer nationality $\rightarrow$ Physical proximity } & 0.83 & 8.37 & 0.00 \\
& Consumer nationality $\rightarrow$ Social proximity & 0.88 & 7.46 & 0.00 \\
\hline
\end{tabular}

Fit statistics: $\chi^{2}=1230.74, p=0.000, \mathrm{df}=518 ; \mathrm{NFI}=0.94 ; \mathrm{NNFI}=0.96 ; \mathrm{CFI}=0.96 ; \mathrm{RMSEA}=0.085$ $(0.081,0.090)$ an individual feels toward the beneficiary and understand their situation, the more likely they are to engage with their cause (Mencl and May 2009; Ghorbani et al. 2013). Among the three dimensions of proximity, social proximity was the most significant predictor of consumer FT engagement, followed by psychological proximity and physical proximity.

Our study also confirmed that consumer FT engagement is conducive to the purchase of FT products $(\beta=0.84$, $t=7.74, p=0.00$ ), thus confirming $\mathrm{H}_{4}$. Indeed, this is in line with previous empirical research that argues that consumers who care about FT issues are more motivated to purchase FT products (Nicholls and Lee 2006; Bondy and Talwar 2011; Chatzidakis et al. 2016; Yamoah et al. 2016). Clearly, this indicates that consumers who actively engage with and support FT issues are willing to purchase FT products, even if this means paying a slightly extra price.

\section{Moderation Analysis}

To examine moderating effects, we adopted the split-group approach, where the initial sample was divided into two subgroups using the median (Sharma et al. 2009). Two models were subsequently estimated for each hypothesized moderating effect: (a) a constrained model, where the path affected by the moderating variable was fixed to 1 ; and (b) a free model, where all paths of the structural model were allowed to be freely estimated. A significant Chi square difference between the two models implies that the moderator variable has a significant effect on the hypothesized association between constructs. The outcomes of this analysis are presented in Table $3 .^{3}$

\footnotetext{
3 We also ran additional analyses based on split groups to examine possible moderating effects of consumer empathic concern and hypocrisy on the association between consumer FT engagement and consumer FT purchasing behavior. With regard to consumer
}

With regard to consumer empathic concern, our results show a strong moderating effect on the link between the three proximity dimensions and consumer FT engagement. In specific, the effect of physical proximity and consumer FT engagement is stronger when the consumers demonstrate higher levels of empathic concern $(\beta=0.36, t=3.10$, $p<0.01)$ than when they express lower levels of empathic concern $(\beta=0.23, t=2.07, p<0.05)\left(\Delta \chi^{2}=2.94, p<0.10\right)$. Besides, the interaction effect between social proximity and consumer FT engagement was marginally higher, when consumers display higher levels of empathic concern $(\beta=0.47$, $t=4.33, p<0.01)$ than they show lower levels of empathic concern $(\beta=0.45, t=3.24, p<0.01)\left(\Delta \chi^{2}=0.52, p<0.10\right)$. Further, empathic concern also exhibited significant associations between psychological proximity and consumer FT engagement. Results reveal that psychological proximity was more strongly related to consumer FT engagement when consumers demonstrated higher levels of empathic concern $(\beta=0.47, t=3.51, p<0.01)$ than when they feel lower levels of empathic concern $(\beta=0.18, t=1.74, p<0.10)$ $\left(\Delta \chi^{2}=5.07, p<0.05\right)$. These findings concur with previous research, which suggests that consumers with empathic concern are more likely to recognize the distress of marginalized producers/workers, which enhances their involvement with

Footnote 3 (continued)

empathic concern, our results show a strong moderating impact $\left(\Delta \chi^{2}(1)=11.76 ; p<0.01\right)$, with the effect of FT consumer engagement on FT purchasing behavior becoming stronger among consumers characterized by high empathic concern $(\beta=0.85, t=4.90$, $p<0.01)$, rather than low-empathic concern $(\beta=0.75, t=4.88$, $p<0.01)$. A strong moderating effect was also revealed in the case of consumer hypocrisy $\left(\Delta \chi^{2}(1)=9.61 ; p<0.01\right)$, where the effect of consumer FT engagement on FT purchasing behavior weakens in the case of consumers in the high hypocrisy group $(\beta=0.87, t=5.82$, $p<0.01$ ), as opposed to consumers who are characterized by low hypocrisy $(\beta=0.80, t=5.14, p>0.01)$. 
Table 3 Results of individual moderating effects

\begin{tabular}{|c|c|c|c|c|}
\hline Main effect & Hypothesized moderating effect & Low empathic concern group & High empathic concern group & $\Delta \chi^{2}(\Delta \mathrm{df}=1)$ \\
\hline \multicolumn{5}{|c|}{ a. Consumer empathic concern as a moderator } \\
\hline $\mathrm{PHP} \rightarrow \mathrm{CEN}$ & $\begin{array}{l}\mathrm{H}_{5 \mathrm{a}}: \text { Effect is stronger when consumer empathic } \\
\text { concern is higher }\end{array}$ & $\begin{array}{l}\beta=0.23 \\
t=2.07 \\
(p<0.05)\end{array}$ & $\begin{array}{l}\beta=0.36 \\
t=3.10 \\
(p<0.01)\end{array}$ & $\begin{array}{l}2.94 \\
(p<0.10)\end{array}$ \\
\hline $\mathrm{SCP} \rightarrow \mathrm{CEN}$ & $\begin{array}{l}\mathrm{H}_{5 \mathrm{~b}}: \text { Effect is stronger when consumer empathic } \\
\text { concern is higher }\end{array}$ & $\begin{array}{l}\beta=0.45 \\
t=3.24 \\
(p<0.01)\end{array}$ & $\begin{array}{l}\beta=0.47 \\
t=4.33 \\
(p<0.01)\end{array}$ & $\begin{array}{l}0.52 \\
(p<0.10)\end{array}$ \\
\hline $\mathrm{PSP} \rightarrow \mathrm{CEN}$ & $\begin{array}{l}\mathrm{H}_{5 \mathrm{c}}: \text { Effect is stronger when consumer empathic } \\
\text { concern is higher }\end{array}$ & $\begin{array}{l}\beta=0.18 \\
t=1.74 \\
(p<0.10)\end{array}$ & $\begin{array}{l}\beta=0.47 \\
t=3.51 \\
(p<0.01)\end{array}$ & $\begin{array}{l}5.07 \\
(p<0.05)\end{array}$ \\
\hline \multicolumn{5}{|c|}{ b. Consumer hypocrisy as a moderator } \\
\hline Main effect & Hypothesized moderating effect & Low hypocrisy group & High hypocrisy group & $\begin{array}{l}\Delta \chi^{2} \\
(\Delta \mathrm{df}=1)\end{array}$ \\
\hline $\mathrm{PHP} \rightarrow \mathrm{CEN}$ & $\begin{array}{l}\mathrm{H}_{6 \mathrm{a}}: \text { Effect is weaker when consumer hypocrisy } \\
\text { is higher }\end{array}$ & $\begin{array}{l}\beta=0.36 \\
t=3.61 \\
(p<0.01)\end{array}$ & $\begin{array}{l}\beta=0.22 \\
t=1.98 \\
(p<0.01)\end{array}$ & $\begin{array}{l}3.13 \\
(p<0.10)\end{array}$ \\
\hline $\mathrm{SCP} \rightarrow \mathrm{CEN}$ & $\begin{array}{l}\mathrm{H}_{6 \mathrm{~b}} \text { : Effect is weaker when consumer hypocrisy } \\
\text { is higher }\end{array}$ & $\begin{array}{l}\beta=0.49 \\
t=4.42 \\
(p<0.01)\end{array}$ & $\begin{array}{l}\beta=0.39 \\
t=3.38 \\
(p<0.01)\end{array}$ & $\begin{array}{l}0.70 \\
(p<0.10)\end{array}$ \\
\hline $\mathrm{PSP} \rightarrow \mathrm{CEN}$ & $\begin{array}{l}\mathrm{H}_{6 \mathrm{c}} \text { : Effect is weaker when consumer hypocrisy } \\
\text { is higher }\end{array}$ & $\begin{array}{l}\beta=0.52 \\
t=4.28 \\
(p<0.01)\end{array}$ & $\begin{array}{l}\beta=0.27 \\
t=2.24 \\
(p<0.05)\end{array}$ & $\begin{array}{l}5.23 \\
(p<0.05)\end{array}$ \\
\hline
\end{tabular}

FT issues (Nicholls and Lee 2006; Doran and Natale 2011; Lee 2016; Hwang and Kim 2018).

The moderating role of consumer hypocrisy on the relationship between each of the three proximity dimensions and consumer FT engagement was also supported. Our results confirmed that the effect of physical proximity on consumer FT engagement weakens in the case of consumers in the high hypocrisy group $(\beta=0.22, t=1.98$, $p<0.01)$, as opposed to consumers who are characterized by low hypocrisy $(\beta=0.36, t=3.61, p<0.01)\left(\Delta \chi^{2}=3.13\right.$, $p<0.10)$. Similarly, the relationship between social proximity and consumer FT engagement wanes when consumers display higher levels of hypocrisy $(\beta=0.39, t=3.38$, $p<0.1)$ as opposed to lower levels of hypocrisy $(\beta=0.49$, $t=4.42, p<0.01)\left(\Delta \chi^{2}=0.70, p<0.10\right)$. Finally, the effect of psychological proximity and consumer FT engagement is weaker in consumers demonstrating higher levels of hypocrisy $(\beta=0.27, t=2.24, p<0.05)$ than those showing lesser levels of hypocrisy $(\beta=0.52, t=4.28, p<0.01)\left(\Delta \chi^{2}=5.23\right.$, $p<0.10)$. Although there are hints in the literature that hypocrisy could influence ethical consumption (Carrington et al. 2016; Gamma et al. 2018), our findings offer a new explanation for the relationship between proximity dimensions and consumer FT engagement. This is in line with the arguments of Reczek et al. (2017), who found that people wilfully ignore information about ethical attributes to avoid emotionally difficult ethical information (e.g., child labor, exploited marginalized farmers) in purchase decisions, suggesting that wilfully ignorant memory is a more morally acceptable form of coping with 'want/should' conflict. In doing so, people stray from embedded beliefs and behavior to satisfy the want self's desire to feel good, even though they may be physically, socially or psychologically proximate to the marginalized producers/workers (Hassan et al. 2016). Hence, the effect of proximity on consumer FT engagement is weakened by hypocrisy as the consumer is able to reconcile self-perception as hypocrite, by justifying and rationalizing his or her actions.

\section{Control Effects}

The role of consumer nationality, whether British or Indian, as a control variable on proximity, was also examined, revealing a significant effect on all three proximity dimensions. Specifically, compared to their British counterparts, Indian consumers perceived higher levels of physical $(\beta=0.86, t=7.08, p=0.00)$, social $(\beta=0.83$, $t=8.37, p=0.00)$, and psychological $(\beta=0.88, t=7.46$, $p=0.00)$ proximity to the marginalized producers/workers. This reinforces that India, being itself an FT producer and a consumer market for FT goods, is geographically nearer to marginalized producers/workers in the 'global south' and thus its consumers are more likely to be engaged with FT issues than British consumers (Doherty 
et al. 2015). The results relating to social proximity can also be explained by the fact that Indian consumers tend to share similar social experiences with marginalized producers/workers and show higher commitment to their wellbeing, as they are more likely to perceive the poor producers/workers as an in-group than British consumers (Doran 2009). Finally, the greater psychological proximity of Indian consumers to FT issues can be attributed to the fact that they may be able to understand plight of the marginalized producers/workers and show higher commitment to their wellbeing, thus, they would want to support them by engaging more with FT products (Nicholls and Lee 2006; Doherty et al. 2015). ${ }^{4}$

\section{Conclusions and Implications}

Our previous analysis has amply demonstrated that consumers engaged with FT are influenced by various proximity dimensions, namely physical, social, and psychological. This association between these proximity dimensions and consumer FT engagement is strengthened by feelings of empathic concern, while the existence of hypocrisy has a detrimental role on this association. In turn, consumer engagement in FT comes to play a dominant role in their lives by affecting their FT purchasing behavior. Our findings also show that nationality plays an important role in consumer FT engagement, with Indian consumers showing higher levels of proximity to marginalized producers/workers compared to their British counterparts.

The findings of our study have important theoretical and managerial implications. Theoretically, we provide key insights into the neglected association of dimensions of proximity (for which we developed a new measurement scale) as a significant predictor of consumer FT engagement. We examine FT consumption behavior through the lens of Social Identity Theory, which stresses that identification with a group (with similar moral values and beliefs) is likely to produce positive outcomes toward a specific product. This extends the research emphasizing the bonds developed through proximity and their impact on ethical consumption, particularly in the FT context (Nicholls and Lee 2006; Doran 2009; Ghorbani et al. 2013). Our study also introduces a previously untested mechanism demonstrating that consumer FT engagement can positively impact FT purchasing behavior. This finds support with the customer engagement literature, which suggests purchasing behavior is a direct consequence of customer engagement (Pansari and Kumar 2017). We also stress the importance of empathic concern and hypocrisy as moderating the impact of proximity on consumer FT engagement. This is in line with prior ethical decision making studies, which argue that familiarity and relationships with the beneficiary could enhance understanding in them (Ballet and Carimentrand 2010). The finding of consumer hypocrisy implies a words-deeds misalignment, which means that even if the consumers are proximate to the beneficiary, they may not actively involve themselves with FT issues (Hassan et al. 2016). Finally, we found country-level effects on the three proximity dimensions, which indicates that proximity is susceptible to cultural differences. This suggests that instead of assuming a universal value of FT, there is a need to account for contextual factors influencing FT consumption in different countries.

Managerially, the strong relationship found between the various proximity dimensions and consumer FT engagement, implies that sound marketing strategies could be used in strengthening consumer proximity to FT issues. This can be achieved, for example, by enhancing the content of advertisements, product labeling, and other information material accompanying FT products, with details about the name and a picture of the producer, so as to ensure that the consumer explicitly identifies the origins of the product. Moreover, retailers can place in-store advertisements, brochures, and even sampling regarding FT products to raise awareness, interest, and likeness among shoppers in their stores to overcome the challenges of proximity. Such a strategy can evoke empathic concern to encourage a sense of personal involvement, and, therefore, engagement with the concept of FT. Furthermore, the organization of social events, such as a 'day in the life' of a marginalized producer (accompanied with images from the country producing the FT products and exhibition of their FT products), would also seriously help to increase proximity between these producers and potential buyers. Finally, companies should take advantage of the growing role of social media as a means of increasing proximity and enhancing consumer engagement and try to demonstrate through them (e.g., using advertisements, uploading specialized articles, participating in discussions) the benefits to consumers and society at large derived from the use of FT products.

\footnotetext{
4 The existence of a control effect of nationality on each of the various proximity dimensions (i.e., physical, social, psychological) implies that there are unique aspects of nationality that can affect consumer FT engagement and purchasing which are not explained by geographic location alone.
} 


\section{Limitations and Future Directions}

This study has number of limitations that proffer many future research directions. First, we examine proximity, which is a component of moral intensity in shaping consumer engagement. More light needs to shed on the remaining components of moral intensity (i.e., magnitude of consequences, probability of effect, social consensus, temporal immediacy, and concentration of effect), as this will help to extend our initial findings. Moreover, the potential role of other antecedent (e.g., animosity) and outcome (e.g., trust) factors of consumer FT engagement is also worth investigating.

Second, while this is the first study to include (apart from developed country-based consumers) a consumer sample from emerging economies, other studies could focus on other emerging economies, such as China, Brazil, and South Africa (Anderson 2018). As FT is increasing its presence in these markets, future studies could also investigate the role of proximity and consumer FT engagement in influencing FT consumer decision-making across countries of different stage of economic development.

Third, we have used self-reported data to measure the drivers and outcomes consumer FT engagement. This might have led to social desirability bias, as data collected from consumers refer to their perceptual and not their actual FT purchasing behavior. This problem could be reduced by observing real time purchasing behavior through ethnographic studies (Carrington et al. 2014) and/ or collecting loyalty card data from retailers selling FT products (Yamoah et al. 2014).

Fourth, we employ a cross-sectional research design to examine consumer perceptions with regard to proximity, FT engagement, empathic concern, hypocrisy, and FT purchasing behavior. Due to the dynamic nature of these issues, future research should embark on longitudinal designs, which can monitor changes over time. In addition, the complex causal nature among these constructs necessitates the greater use of experimental studies among consumers from different nationalities, demographic profiles, and psychographic backgrounds.

Fifth, although our study has shown that there are marked differences in the way physical, social, and psychological proximity is perceived among consumers in developed, as opposed to emerging economies, there are indications in the literature (e.g., Doran 2009) that consumers from two different developed countries may also have different motivations for FT consumption. Hence, future research should explore such differences in proximity perceptions of consumers between developed countries (as well as of consumers between emerging economies).

Finally, our conceptual model could be augmented with additional constructs with a potential on FT consumer attitudes and behavior. For example, the 'Big Five' personality traits (i.e., openness, extraversion, conscientiousness, agreeableness, and neuroticism) could play a key role in predicting consumer decision-making related to FT products (Mischel and Shoda 1995, 2002). Moreover, since the results of our control analysis with regard to nationality underscore a potential association of culture with FT, it would be interesting to explore the unique role of Hofstede's (1984) cultural orientation dimensions (i.e., uncertainty avoidance, power distance, masculinity, individualism, and long-term orientation) on influencing consumer FT engagement and purchasing behaviors.

\section{Compliance with Ethical Standards}

Conflict of interest The authors declare that he has no conflict of interest.

Ethical Approval All procedures performed in studies involving human participants were in accordance with the ethical standards of the institutional research guidelines.

Informed Consent Informed consent was obtained from all individual participants included in the study.

Open Access This article is distributed under the terms of the Creative Commons Attribution 4.0 International License (http://creativeco mmons.org/licenses/by/4.0/), which permits unrestricted use, distribution, and reproduction in any medium, provided you give appropriate credit to the original author(s) and the source, provide a link to the Creative Commons license, and indicate if changes were made.

\section{Appendix}

See Tables 4 and 5. 


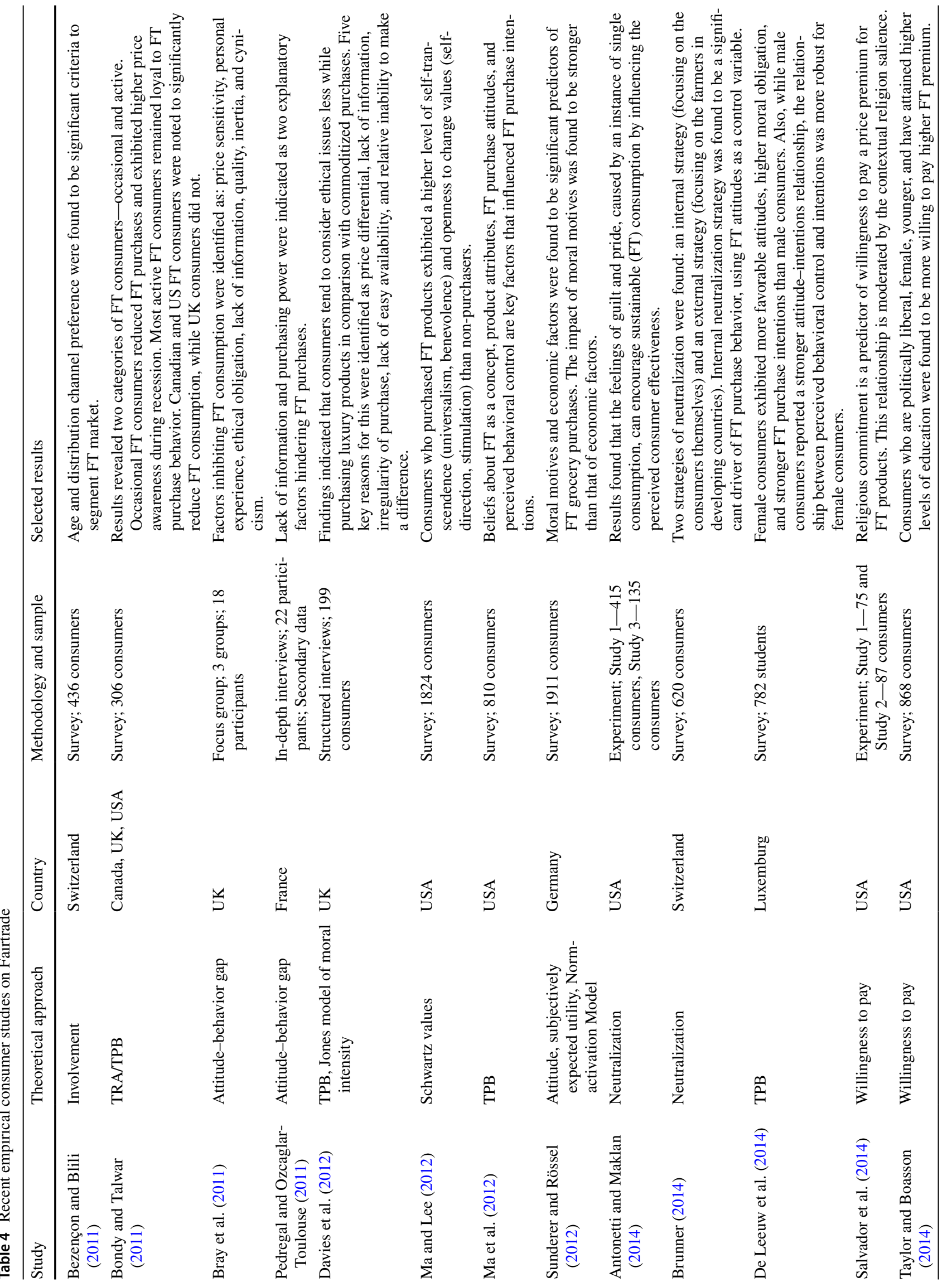




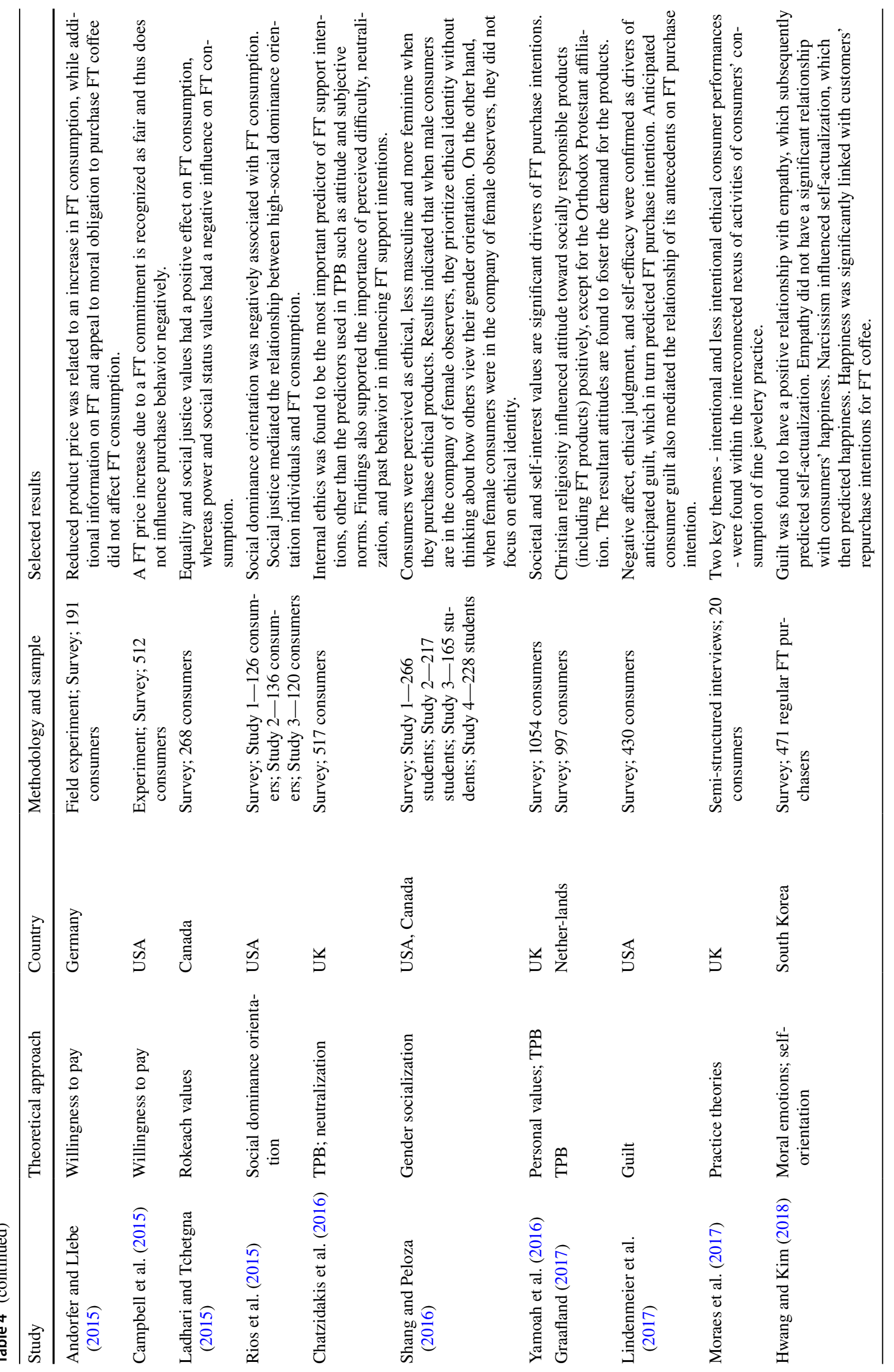


Table 5 Measurement scales and their sources

\begin{tabular}{|c|c|c|c|}
\hline \multirow[t]{4}{*}{ PHP-physical proximity } & PHP1 & $\begin{array}{l}\text { I consider myself physically close to the poor pro- } \\
\text { ducers/workers producing Fairtrade products }\end{array}$ & Self-developed \\
\hline & PHP2 & $\begin{array}{l}\text { I can see the plight of the poor producers/workers } \\
\text { producing Fairtrade products }\end{array}$ & \\
\hline & PHP3 & $\begin{array}{l}\text { I often feel a physical connection between poor } \\
\text { producers/workers producing Fairtrade products } \\
\text { and myself }\end{array}$ & \\
\hline & PHP4 & $\begin{array}{l}\text { I consider myself physically distant from the poor } \\
\text { producers/workers producing Fairtrade products } \\
\text { (R) }\end{array}$ & \\
\hline \multirow[t]{5}{*}{ SCP-social proximity } & SCP1 & $\begin{array}{l}\text { I consider myself socially and culturally close to } \\
\text { the poor producers/workers producing Fairtrade } \\
\text { products }\end{array}$ & Self-developed \\
\hline & $\mathrm{SCP} 2$ & $\begin{array}{l}\text { I often feel a social connection between poor produc- } \\
\text { ers/workers producing Fairtrade products and } \\
\text { myself }\end{array}$ & \\
\hline & $\mathrm{SCP} 3$ & $\begin{array}{l}\text { I consider a social and cultural gap between myself } \\
\text { and the poor producers/workers producing Fair- } \\
\text { trade products }(\mathrm{R})\end{array}$ & \\
\hline & $\mathrm{SCP} 4$ & $\begin{array}{l}\text { My cultural values, beliefs, attitudes, and traditions } \\
\text { are similar to those of the poor producers/workers } \\
\text { producing Fairtrade products }\end{array}$ & \\
\hline & SCP5 & $\begin{array}{l}\text { I am familiar with the values, norms, customs, and } \\
\text { beliefs of the poor producers/workers producing } \\
\text { Fairtrade products }\end{array}$ & \\
\hline \multirow[t]{5}{*}{ PSP-psychological proximity } & PSP1 & $\begin{array}{l}\text { I can understand the plight of the poor producers/ } \\
\text { workers producing Fairtrade products }\end{array}$ & Self-developed \\
\hline & PSP2 & $\begin{array}{l}\text { I consider myself psychologically close to the poor } \\
\text { producers/workers producing Fairtrade products }\end{array}$ & \\
\hline & PSP3 & $\begin{array}{l}\text { I often feel a psychological connection between poor } \\
\text { producers/workers producing Fairtrade products } \\
\text { and myself. }\end{array}$ & \\
\hline & PSP4 & $\begin{array}{l}\text { I consider a psychological gap between myself and } \\
\text { the poor producers/workers producing Fairtrade } \\
\text { products. }(\mathrm{R})\end{array}$ & \\
\hline & PSP5 & $\begin{array}{l}\text { I can identify with the poor producers/workers pro- } \\
\text { ducing Fairtrade products }\end{array}$ & \\
\hline \multirow[t]{15}{*}{ CEN-Fairtrade consumer engagement } & & Enthusiasm & So et al. (2014) \\
\hline & CEE1 & I am heavily into Fairtrade & \\
\hline & CEE2 & I am passionate about Fairtrade & \\
\hline & CEE3 & I am enthusiastic about Fairtrade & \\
\hline & CEE4 & I feel excited about Fairtrade & \\
\hline & & Attention & \\
\hline & CEA1 & I would like to learn more about Fairtrade & \\
\hline & CEA2 & I pay a lot of attention to anything about Fairtrade & \\
\hline & CEA3 & Anything related to Fairtrade grabs my attention & \\
\hline & CEA4 & I concentrate a lot on Fairtrade. & \\
\hline & CEA5 & I like learning more about Fairtrade & \\
\hline & & Absorption & \\
\hline & CEB1 & $\begin{array}{l}\text { When I am interacting with Fairtrade, I forget every- } \\
\text { thing else around me }\end{array}$ & \\
\hline & CEB2 & Time flies when I am interacting with Fairtrade & \\
\hline & CEB3 & $\begin{array}{l}\text { When I am interacting with Fairtrade, I get carried } \\
\text { away }\end{array}$ & \\
\hline
\end{tabular}


Table 5 (continued)

CEM-consumer empathic concern

CHY-Consumer hypocrisy

FPB-Fairtrade purchasing behavior CEB4 When interacting with Fairtrade, it is difficult to
detach myself

CEB5 When interacting with Fairtrade intensely, I feel
happy Interaction

CEI1 In general, I like to get involved in Fairtrade community discussions

CEI2 I am someone who enjoys interacting with likeminded others about Fairtrade

CEI3 I am someone who likes actively participating in Fairtrade-related discussions

CEI4 In general, I thoroughly enjoy exchanging ideas with other people related to Fairtrade

CEI5 I often participate in activities related to Fairtrade

CEM1 I would describe myself as a pretty soft-hearted person

CEM2 When I see someone being treated unfairly, I sometimes don't feel very much pity for him/her (R)

CEM3 When I see someone being taken advantage of, I feel kind of protective toward him/her

CEM4 Other people's misfortunes do not usually disturb me a great deal $(\mathrm{R})$

CEM5 I am often quite touched by things that I see happen

CEM6 I often have tender, concerned feelings for people less fortunate than me

CEM7 Sometimes I don't feel very sorry for other people when they are having problems (R)

CHY1 What I say and do are two different things

CHY2 I pretend to be something that I am not

CHY3 I do exactly what I say (R)

CHY4 I put my words into action (R)

CHY5 I fail to practise what I preach.

CHY6 I pretend to have beliefs and feelings that I do not really have

FPB1 I spend a lot of time buying Fairtrade products, compared to other products

PB3 When there is a choice, I always choose Fairtrade products

FPB4 I do not buy products from companies that I know use sweatshop labor, child labor, or other poor working conditions

FPB5 I am willing to pay more for Fairtrade products, even when there is a cheaper alternative
Davis (1980), Kamdar et al. (2006)

Wagner et al. (2009)

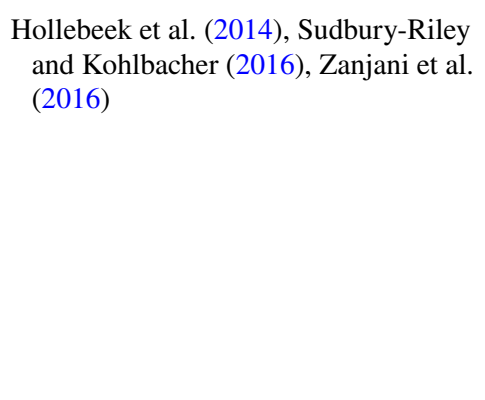

The sign ( $\mathrm{R})$ refers to a reverse item 


\section{References}

Adams, M., \& Raisborough, J. (2008). What can sociology say about FairTrade? Class, reflexivity and ethical consumption. Sociology, 42(6), 1165-1182.

Adams, M., \& Raisborough, J. (2010). Making a difference: ethical consumption and the everyday. The British Journal of Sociology, 61(2), 256-274.

Alexander, A., \& Nicholls, A. (2006). Rediscovering consumer-producer involvement: A network perspective on fair trade marketing. European Journal of Marketing, 40(11/12), 1236-1253.

Anderson, M. (2018). Fair trade and consumer social responsibility: Exploring consumer citizenship as a driver of social and environmental change. Management Decision, 56(3), 634-651.

Anderson, J. C., \& Gerbing, D. W. (1988). Structural equation modeling in practice: A review and recommended two-step approach. Psychological Bulletin, 103(3), 411-423.

Andorfer, V. A., \& Liebe, U. (2012). Research on fair trade consumption-A review. Journal of Business Ethics, 106(4), 415-435.

Andorfer, V. A., \& Liebe, U. (2015). Do information, price, or morals influence ethical consumption? A natural field experiment and customer survey on the purchase of Fair Trade coffee. Social Science Research, 52, 330-350.

Antonetti, P., \& Maklan, S. (2014). Feelings that make a difference: How guilt and pride convince consumers of the effectiveness of sustainable consumption choices. Journal of Business Ethics, 124(1), 117-134.

Ashforth, B. E., \& Mael, F. (1989). Social identity theory and the organization. Academy of Management Review, 14(1), 20-39.

Ballet, J., \& Carimentrand, A. (2010). Fair trade and the depersonalization of ethics. Journal of Business Ethics, 92(2), 317-330.

Basil, D. Z., Ridgway, N. M., \& Basil, M. D. (2008). Guilt and giving: A process model of empathy and efficacy. Psychology \& Marketing, 25(1), 1-23.

Basu, A. K., \& Hicks, R. L. (2008). Label performance and the willingness to pay for Fair Trade coffee: a cross-national perspective. International Journal of Consumer Studies, 32(5), 470-478.

Batson, C. D., Collins, E., \& Powell, A. A. (2006). Doing business after the fall: The virtue of moral hypocrisy. Journal of Business Ethics, 66(4), 321-335.

Batson, C. D., Dyck, J. L., Brandt, J. R., Batson, J. G., Powell, A. L., McMaster, M. R., et al. (1988). Five studies testing two new egoistic alternatives to the empathy-altruism hypothesis. Journal of Personality and Social Psychology, 55(1), 52.

Bentler, P. M. (2008). Structural equations program manual. Encino, CA: Multivariate Software Inc.

Bezençon, V., \& Blili, S. (2011). Segmenting the market through the determinants of involvement: The case of fair trade. Psychology \& Marketing, 28(7), 682-708.

Bondy, T., \& Talwar, V. (2011). Through thick and thin: How fair trade consumers have reacted to the global economic recession. Journal of Business Ethics, 101(3), 365-383.

Boschma, R. (2005). Proximity and innovation: A critical assessment. Regional Studies, 39(1), 61-74.

Boulstridge, E., \& Carrigan, M. (2000). Do consumers really care about corporate responsibility? Highlighting the attitudebehaviour gap. Journal of Communication Management, 4(4), 355-368.

Bowden, J. L. H. (2009). The process of customer engagement: A conceptual framework. Journal of Marketing Theory and Practice, 17(1), 63-74.

Bray, J., Johns, N., \& Kilburn, D. (2011). An exploratory study into the factors impeding ethical consumption. Journal of Business Ethics, 98(4), 597-608.
Brunner, T. A. (2014). Applying neutralization theory to fair trade buying behaviour. International Journal of Consumer Studies, 38(2), 200-206.

Byrne, B. M. (2006). Structural equation modelling with EQS: Basic concepts, applications, and programming (2nd ed.). London: Lawrence Erlbaum Associates.

Cailleba, P., \& Casteran, H. (2010). Do ethical values work? A quantitative study of the impact of fair trade coffee on consumer behavior. Journal of Business Ethics, 97(4), 613-624.

Campbell, C. L., Heinrich, D., \& Schoenmüller, V. (2015). Consumers' reaction to fair trade motivated price increases. Journal of Retailing and Consumer Services, 24, 79-84.

Carrington, M. J., Neville, B. A., \& Whitwell, G. J. (2010). Why ethical consumers don't walk their talk: Towards a framework for understanding the gap between the ethical purchase intentions and actual buying behaviour of ethically minded consumers. Journal of Business Ethics, 97(1), 139-158.

Carrington, M. J., Neville, B. A., \& Whitwell, G. J. (2014). Lost in translation: Exploring the ethical consumer intention-behavior gap. Journal of Business Research, 67(1), 2759-2767.

Carrington, M. J., Zwick, D., \& Neville, B. (2016). The ideology of the ethical consumption gap. Marketing Theory, 16(1), 21-38.

Chang, C. T. (2012). Are guilt appeals a panacea in green advertising? The right formula of issue proximity and environmental consciousness. International Journal of Advertising, 31(4), 741-771.

Chatzidakis, A., Kastanakis, M., \& Stathopoulou, A. (2016). Sociocognitive determinants of consumers' support for the fair trade movement. Journal of Business Ethics, 133(1), 95-109.

Chowdhury, R. M., \& Fernando, M. (2014). The relationships of empathy, moral identity and cynicism with consumers' ethical beliefs: The mediating role of moral disengagement. Journal of Business Ethics, 124(4), 677-694.

Churchill, G. A., Jr. (1979). A paradigm for developing better measures of marketing constructs. Journal of Marketing Research, 16(1), 64-73.

Davies, I. A., \& Doherty, B. (2018). Balancing a hybrid business model: The search for equilibrium at Cafédirect. Journal of Business Ethics. https://doi.org/10.1007/s10551-018-3960-9.

Davies, I. A., Lee, Z., \& Ahonkhai, I. (2012). Do consumers care about ethical-luxury? Journal of Business Ethics, 106(1), 37-51.

Davis, M. H. (1980). A multidimensional approach to individual differences in empathy. JSAS Catalog of Selected Documents in Psychology, 10, 85.

Davis, M. H. (1983). The effects of dispositional empathy on emotional reactions and helping: A multidimensional approach. Journal of Personality, 51(2), 167-184.

De Ferran, F., \& Grunert, K. G. (2007). French fair trade coffee buyers' purchasing motives: An exploratory study using means-end chains analysis. Food Quality and Preference, 18(2), 218-229.

De Leeuw, A., Valois, P., Morin, A. J., \& Schmidt, P. (2014). Gender differences in psychosocial determinants of university students' intentions to buy fair trade products. Journal of Consumer Policy, 37(4), 485-505.

De Pelsmacker, P., Driesen, L., \& Rayp, G. (2005). Do consumers care about ethics? Willingness to pay for fair-trade coffee. Journal of Consumer Affairs, 39(2), 363-385.

Doherty, B., Davies, I. A., \& Tranchell, S. (2013). Where now for fair trade? Business History, 55(2), 161-189.

Doherty, B., Smith, A., \& Parker, S. (2015). Fair Trade market creation and marketing in the Global South. Geoforum, 67, 158-171.

Doran, C. J. (2009). The role of personal values in fair trade consumption. Journal of Business Ethics, 84(4), 549-563.

Doran, C. J. (2010). Fair trade consumption: In support of the outgroup. Journal of Business Ethics, 95(4), 527-541. 
Doran, C. J., \& Natale, S. M. (2011). $\dot{\varepsilon} \mu \pi \alpha \dot{\theta} \theta \varepsilon ı \alpha$ (Empatheia) and caritas: The role of religion in fair trade consumption. Journal of Business Ethics, 98(1), 1-15.

Fornell, C., \& Larcker, D. F. (1981). Structural equation models with unobservable variables and measurement error: Algebra and statistics. Journal of Marketing Research, 18(1), 382-388.

Gamma, K., Mai, R., \& Loock, M. (2018). The double-edged sword of ethical nudges: Does Inducing hypocrisy help or hinder the adoption of pro-environmental behaviors? Journal of Business Ethics. https://doi.org/10.1007/s10551-018-3930-2.

Ghorbani, M., Liao, Y., Çayköylü, S., \& Chand, M. (2013). Guilt, shame, and reparative behavior: The effect of psychological proximity. Journal of Business Ethics, 114(2), 311-323.

Golding, K., \& Peattie, K. (2005). In search of a golden blend: Perspectives on the marketing of fair trade coffee. Sustainable Development, 13(3), 154-165.

Graafland, J. (2017). Religiosity, attitude, and the demand for socially responsible products. Journal of Business Ethics, 144(1), 121-138.

Grau, S. L., \& Folse, J. A. G. (2007). Cause-related marketing (CRM): The influence of donation proximity and message-framing cues on the less-involved consumer. Journal of Advertising, 36(4), 19-33.

Gupta, S., Pansari, A., \& Kumar, V. (2018). Global customer engagement. Journal of International Marketing, 26(1), 4-29.

Hair, J. F., Jr., Black, W. C., Babin, B. J., \& Anderson, R. E. (2014). Multivariate data analysis (new int. ed.). Harlow: Pearson Education.

Hassan, L. M., Shiu, E., \& Shaw, D. (2016). Who says there is an intention-behaviour gap? Assessing the empirical evidence of an intention-behaviour gap in ethical consumption. Journal of Business Ethics, 136(2), 219-236.

Hofstede, G. (1984). National cultures revisited. Asia Pacific Journal of Management, 2(1), 22-28.

Hollebeek, L. D., Glynn, M. S., \& Brodie, R. J. (2014). Consumer brand engagement in social media: Conceptualization, scale development and validation. Journal of Interactive Marketing, 28(2), 149-165.

Howard, P. H., \& Allen, P. (2010). Beyond organic and fair trade? An analysis of ecolabel preferences in the United States. Rural Sociology, 75(2), 244-269.

Hwang, K., \& Kim, H. (2018). Are ethical consumers happy? Effects of ethical consumers' motivations based on empathy versus self-orientation on their happiness. Journal of Business Ethics, 151(2), 579-598.

Jones, T. M. (1991). Ethical decision making by individuals in organizations: An issue-contingent model. Academy of Management Review, 16(2), 366-395.

Kamdar, D., McAllister, D. J., \& Turban, D. B. (2006). “ All in a day's work": how follower individual differences and justice perceptions predict OCB role definitions and behavior. Journal of Applied Psychology, 91(4), 841-855.

Kim, S. J., \& Kou, X. (2014). Not all empathy is equal: How dispositional empathy affects charitable giving. Journal of Nonprofit \& Public Sector Marketing, 26(4), 312-334.

Kim, G. S., Lee, G. Y., \& Park, K. (2010). A cross-national investigation on how ethical consumers build loyalty toward fair trade brands. Journal of Business Ethics, 96(4), 589-611.

Kline, R. B. (2005). Principles and practices of structural equation modeling (2nd ed.). New York: Guilford Press.

Kumar, V., \& Pansari, A. (2016). Competitive advantage through engagement. Journal of Marketing Research, 53(4), 497-514.

Ladhari, R., \& Tchetgna, N. M. (2015). The influence of personal values on Fair Trade consumption. Journal of Cleaner Production, 87, 469-477.
Lee, E. J. (2016). Empathy can increase customer equity related to prosocial brands. Journal of Business Research, 69(9), 3748-3754.

Lindell, M. K., \& Whitney, D. J. (2001). Accounting for common method variance in cross-sectional research designs. Journal of Applied Psychology, 86(1), 114-121.

Lindenmeier, J., Lwin, M., Andersch, H., Phau, I., \& Seemann, A. K. (2017). Anticipated consumer guilt: An investigation into its antecedents and consequences for Fair-Trade consumption. Journal of Macromarketing, 37(4), 444-459.

Loureiro, M. L., \& Lotade, J. (2005). Do fair trade and eco-labels in coffee wake up the consumer conscience? Ecological Economics, 53(1), 129-138.

Lowry, P. B., D’Arcy, J., Hammer, B., \& Moody, G. D. (2016). "Cargo Cult" science in traditional organization and information systems survey research: A case for using nontraditional methods of data collection, including Mechanical Turk and online panels. The Journal of Strategic Information Systems, 25(3), 232-240.

Ma, Y. J., \& Lee, H. H. (2012). Understanding consumption behaviours for fair trade non-food products: Focusing on self-transcendence and openness to change values. International Journal of Consumer Studies, 36(6), 622-634.

Ma, Y. J., Littrell, M. A., \& Niehm, L. (2012). Young female consumers' intentions toward fair trade consumption. International Journal of Retail \& Distribution Management, 40(1), 41-63.

Mahé, T. (2010). Are stated preferences confirmed by purchasing behaviours? The case of fair trade-certified Bananas in Switzerland. Journal of Business Ethics, 92(2), 301-315.

McFadden, D. (1974). Conditional logit analysis of qualitative choice behavior. In P. Zarembka (Ed.), Frontiers in econometrics (pp. 105-142). New York: Academic Press.

Mencl, J., \& May, D. R. (2009). The effects of proximity and empathy on ethical decision-making: An exploratory investigation. Journal of Business Ethics, 85(2), 201-226.

Merz, M. A., Zarantonello, L., \& Grappi, S. (2018). How valuable are your customers in the brand value co-creation process? The development of a Customer Co-creation Value (CCCV) Scale. Journal of Business Research, 82, 79-89.

Mischel, W., \& Shoda, Y. (1995). A cognitive-affective system theory of personality: Reconceptualizing situations, dispositions, dynamics, and invariance in personality structure. Psychological Review, 102(2), 246-278.

Mischel, W., Shoda, Y., \& Mendoza-Denton, R. (2002). Situationbehavior profiles as a locus of consistency in personality. Current Directions in Psychological Science, 11(2), 50-54.

Mohr, L. A., \& Webb, D. J. (2005). The effects of corporate social responsibility and price on consumer responses. Journal of Consumer Affairs, 39(1), 121-147.

Moore, G. (2004). The fair trade movement: Parameters, issues and future research. Journal of Business Ethics, 53(1-2), 73-86.

Moraes, C., Carrigan, M., Bosangit, C., Ferreira, C., \& McGrath, M. (2017). Understanding ethical luxury consumption through practice theories: A study of fine jewellery purchases. Journal of Business Ethics, 145(3), 525-543.

Narasimhan, L., Srinivasan, K., \& Sudhir, K. (2015). Marketing science in emerging markets. Marketing Science, 34(4), 473-479.

Nicholls, A., \& Huybrechts, B. (2016). Sustaining inter-organizational relationships across institutional logics and power asymmetries: The case of fair trade. Journal of Business Ethics, 135(4), 699-714

Nicholls, A., \& Lee, N. (2006). Purchase decision-making in fair trade and the ethical purchase 'gap': 'Is there a fair trade twix?'. Journal of Strategic Marketing, 14(4), 369-386.

Osburg, V. S., Strack, M., Conroy, D. M., \& Toporowski, W. (2017). Unveiling ethical product features: The importance of an elaborated information presentation. Journal of Cleaner Production, $162,1582-1591$. 
Ozcaglar-Toulouse, N., Shiu, E., \& Shaw, D. (2006). In search of fair trade: ethical consumer decision making in France. International Journal of Consumer Studies, 30(5), 502-514.

Pansari, A., \& Kumar, V. (2017). Customer engagement: The construct, antecedents, and consequences. Journal of the Academy of Marketing Science, 45(3), 294-311.

Park, H. J., \& Lin, L. M. (2018). Exploring attitude-behavior gap in sustainable consumption: Comparison of recycled and upcycled fashion products. Journal of Business Research. https://doi. org/10.1016/j.jbusres.2018.08.025.

Peattie, K., \& Samuel, A. (2018). Fairtrade towns as unconventional networks of ethical activism. Journal of Business Ethics, 153(1), 265-282.

Pedregal, V. D., \& Ozcaglar-Toulouse, N. (2011). Why does not everybody purchase fair trade products? The question of the fairness of fair trade products' consumption for consumers. International Journal of Consumer Studies, 35(6), 655-660.

Podsakoff, P. M., \& Organ, D. W. (1986). Self-reports in organizational research: Problems and prospects. Journal of Management, 12(4), 531-544.

Poelman, A., Mojet, J., Lyon, D., \& Sefa-Dedeh, S. (2008). The influence of information about organic production and fair trade on preferences for and perception of pineapple. Food Quality and Preference, 19(1), 114-121.

Raynolds, L. T. (2000). Re-embedding global agriculture: The international organic and fair trade movements. Agriculture and Human Values, 17(3), 297-309.

Reczek, R. W., Irwin, J. R., Zane, D. M., \& Ehrich, K. R. (2017). That's not how I remember it: Willfully ignorant memory for ethical product attribute information. Journal of Consumer Research, 45(1), 185-207.

Reese, G., \& Kohlmann, F. (2015). Feeling global, acting ethically: Global identification and fairtrade consumption. The Journal of Social Psychology, 155(2), 98-106.

Rios, K., Finkelstein, S. R., \& Landa, J. (2015). Is there a "fair" in fair-trade? Social dominance orientation influences perceptions of and preferences for fair-trade products. Journal of Business Ethics, 130(1), 171-180.

Salvador, R. O., Merchant, A., \& Alexander, E. A. (2014). Faith and fair trade: The moderating role of contextual religious salience. Journal of Business Ethics, 121(3), 353-371.

Sen, S., \& Bhattacharya, C. B. (2001). Does doing good always lead to doing better? Consumer reactions to corporate social responsibility. Journal of Marketing Research, 38(2), 225-243.

Shang, J., \& Peloza, J. (2016). Can "real" men consume ethically? How ethical consumption leads to unintended observer inference. Journal of Business Ethics, 139(1), 129-145.

Sharma, D., Borna, S., \& Stearns, J. M. (2009). An investigation of the effects of corporate ethical values on employee commitment and performance: Examining the moderating role of perceived fairness. Journal of Business Ethics, 89(2), 251-260.

Shaw, D., Grehan, E., Shiu, E., Hassan, L., \& Thomson, J. (2005). An exploration of values in ethical consumer decision making. Journal of Consumer Behaviour, 4(3), 185-200.

Shaw, D., McMaster, R., \& Newholm, T. (2016). Care and commitment in ethical consumption: An exploration of the 'attitude-behaviour gap'. Journal of Business Ethics, 136(2), 251-265.

Shaw, D., Shiu, E., \& Clarke, I. (2000). The contribution of ethical obligation and self-identity to the theory of planned behaviour: An exploration of ethical consumers. Journal of Marketing Management, 16(8), 879-894.

Sheth, J. N. (2011). Impact of emerging markets on marketing: Rethinking existing perspectives and practices. Journal of Marketing, 75(4), 166-182.
Smith, S. M., Roster, C. A., Golden, L. L., \& Albaum, G. S. (2016). A multi-group analysis of online survey respondent data quality: Comparing a regular USA consumer panel to MTurk samples. Journal of Business Research, 69(8), 3139-3148.

So, K. K. F., King, C., \& Sparks, B. (2014). Customer engagement with tourism brands: Scale development and validation. Journal of Hospitality \& Tourism Research, 38(3), 304-329.

Stump, R. L., \& Heide, J. B. (1996). Controlling supplier opportunism in industrial relationships. Journal of Marketing Research, 33(4), 431-441.

Sudbury-Riley, L., \& Kohlbacher, F. (2016). Ethically minded consumer behavior: Scale review, development, and validation. Journal of Business Research, 69(8), 2697-2710.

Sunderer, G., \& Rössel, J. (2012). Morality or economic interest? The impact of moral motives and economic factors on the purchase of fair trade groceries. International Journal of Consumer Studies, 36(2), 244-250.

Tajfel, H., \& Turner, J. C. (1979). An integrative theory of intergroup conflict. In W. G. Austin \& S. Worchel (Eds.), The social psychology of intergroup relations (pp. 33-47). Chicago, IL: Nelson-Hall.

Taylor, J. E., \& Boasson, V. (2014). Who buys fair trade and why (or why not)? A random survey of households. Journal of Consumer Affairs, 48(2), 418-430.

Thompson, C. J., \& Coskuner-Balli, G. (2007). Countervailing market responses to corporate co-optation and the ideological recruitment of consumption communities. Journal of Consumer Research, 34(2), 135-152.

Trudel, R., \& Cotte, J. (2009). Does it pay to be good? MIT Sloan Management Review, 50(2), 61-68.

Turner, J. C., \& Tajfel, H. (1986). The social identity theory of intergroup behavior. Psychology of Intergroup Relations, 5, 7-24.

Van Doorn, J., Lemon, K. N., Mittal, V., Nass, S., Pick, D., Pirner, P., et al. (2010). Customer engagement behavior: Theoretical foundations and research directions. Journal of Service Research, 13(3), 253-266.

Varul, M. Z. (2009). Ethical selving in cultural contexts: Fairtrade consumption as an everyday ethical practice in the UK and Germany. International Journal of Consumer Studies, 33(2), 183-189.

Venkatraman, N., \& Prescott, J. E. (1990). Environment-strategy coalignment: An empirical test of its performance implications. Strategic Management Journal, 11(1), 1-23.

Vivek, S. D., Beatty, S. E., Dalela, V., \& Morgan, R. M. (2014). A generalized multidimensional scale for measuring customer engagement. Journal of Marketing Theory and Practice, 22(4), 401-420.

Vivek, S. D., Beatty, S. E., \& Morgan, R. M. (2012). Customer engagement: Exploring customer relationships beyond purchase. Journal of Marketing Theory and Practice, 20(2), 122-146.

Wagner, T., Lutz, R. J., \& Weitz, B. A. (2009). Corporate hypocrisy: Overcoming the threat of inconsistent corporate social responsibility perceptions. Journal of Marketing, 73(6), 77-91.

Ward, M. K., \& Dahl, D. W. (2014). Should the devil sell Prada? Retail rejection increases aspiring consumers' desire for the brand. Journal of Consumer Research, 41(3), 590-609.

Yamoah, F. A., Duffy, R., Petrovici, D., \& Fearne, A. (2016). Towards a framework for understanding fairtrade purchase intention in the mainstream environment of supermarkets. Journal of Business Ethics, 136(1), 181-197.

Yamoah, F. A., Fearne, A., \& Duffy, R. (2014). Exploring supermarket loyalty card analysis to identify who buys fairtrade. The International Review of Retail, Distribution and Consumer Research, 24(3), 328-346. 
Zanjani, S. H., Milne, G. R., \& Miller, E. G. (2016). Procrastinators' online experience and purchase behavior. Journal of the Academy of Marketing Science, 44(5), 568-585.

Zhu, J., Tatachari, S., \& Chattopadhyay, P. (2017). Newcomer Identification: Trends, Antecedents, Moderators, and Consequences. Academy of Management Journal, 60(3), 855-879.
Publisher's Note Springer Nature remains neutral with regard to jurisdictional claims in published maps and institutional affiliations. 